\title{
The Psychological Wellbeing of Palestinian Children Living among Israeli Settlements in Hebron old city
}

\author{
Dr. Amer Shehadeh \\ Ph.D. in Psychology, Head of Psychology Department, Al Istiqlal University, Palestine \\ Email: amer.shehadeh@pass.ps
}

\begin{abstract}
:
For more than ten decades, the Palestinian Occupied Territories are marked by a protracted political conflict. During this conflict, more than 300 settlements have been built in side West Bank, Gaza, and east Jerusalem "Occupied Palestinian Territories", since that time the conflict between Palestinian and Israeli occupation forces still ongoing. One of the most important result of this occupation and conflict is the suffering of Palestinian living among these Israeli settlements. Therefore, this study aimed at gaining insight into the impact of living within this situation on the children and adolescents' psychological wellbeing.

357 8-18 years olds Palestinian children took part; Two self-report questionnaires: the UCLAPTSD-Reaction Index, investigating symptoms of posttraumatic stress, and the Strengths and Difficulties Questionnaires, looking at overall psychological problems, were filed by children themselves, mothers and teachers. Descriptive analyses investigated mental health differences between both variables, gender and age and the mental health outcomes.

This study shows the important impact of being lived among israile settlements on the psychological wellbeing of Palestinian, above, girls, younger adolescents, also reported higher scores on both questionnaires, the study urges for more psychological care and support for family members - in particular children.
\end{abstract}

key words: Psychological wellbeing, Palestine, Children, Israeli settlements, Hebron old city. 


\section{Publication Date: 5-8-2021 ISSN:2706-6495}

الملخص:

لأكثر من عثرة عقود، تميزت الأراضي الفلسطينية المحتلة بنزاع سياسي طويل الأمد. خلال هذا الصراع، تم بناء أكثر من

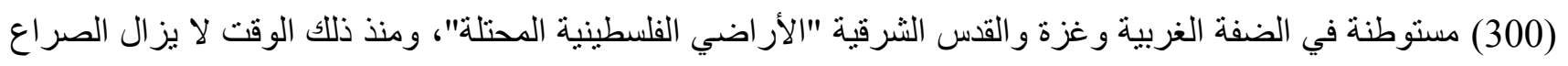
بين قوات الاحتلال الاسر ائلي و الفلسطينين مستمر اً. من أهم نتائج هذا الاحتلال والصر اع معاناة الفلسطينيين الذين يعيشون وسط هذه المستوطنات الإسرائيلية. لذلك، هدفت هذه الدر اسة إلى التعرف على نأثثير العيش ضمن غلاف المستوطنات الاسر ائيلية على الصحة النفسية للأطفال و المر اهقين. شارك 357 طفل فلسطيني تتر اوح أعمار هم بين (8) و (18) سنة. حيث تم تقديم استبيانين للتقرير الذاتي: مؤشر اعر اض ما بعد

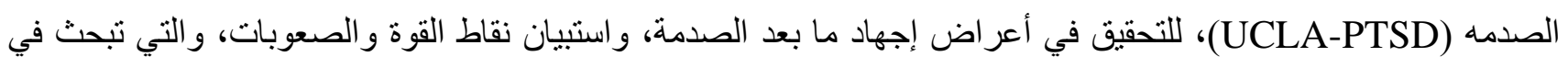
المشكلات النفسية الثاملة، من قبل الأطفال أنفسهم والأمهات و المعلمين. استخدم الباحث التحليل الوصفي للوصل وبحث الاختلافات في الصحة النفسية تبعا لمتغير ات، الجنس و العمر. اظهر نتائج هذه الدر اسة وبينت التاثير الهام و السلبي للعيش بين المستوطنات الإسر ائبلية على الصحة النفسية للفلسطينيين، علاوة على ذلك فقد اظهر الفتيات و المر اهقين الأصغر سنًا درجات أعلى في كلا الاستبيانين مما يدل على وجود تاثثير سلبي على صحتهم النفسية أكثر من الذكور او الاكبر سنا. وتحث الدراسة على مزيد من الرعاية والدعم النفسي لأفراد الأسرة التي تعيش هذه الظروف بشكل عام وبشكل خاص الاطفال. الكلمات المفتاحية: الصحة النفسية، فلسطين، أطفال، مستوطنات إسر ائيلية، مدينة الخليل القديمة.

\section{Introduction:}

The ongoing political conflict in the Occupied Palestinian Territories (OPT) makes identifying the consequence of well-being and quality of life in the civilians particularly challenging. While increasing attention is being paid to the deleterious effects of political violence on the mental health of civilian populations (Jordans, 2010; Hasanovic, et al; 2006; Qouta, 2003). The (OPT) have been under the Israeli military occupation for over fifty years which included control over the Palestinian land, movement of people, access to resources (e.g. water, food) and employment (WAFA, 2021; Amnesty International, 2017). In all political violence, conflict and wars, the victims in most cases perceived as a highly impacting crises with large consequences and mostly they are civilians (Hammad ,J and Tribe, R, 2020 ; Thabet, et al, 2008; Hasanovic, et al; 2006; Qouta, 2003), this violence severely impact mental health and quality of life for all people involved in conflict (Hammad ,J and Tribe, R, 2020; World Health Organization, 2013). One of the expected important results is increasing number of children throughout the world who are growing up in the middle of war and political violence, and occupation. 
Children who exposed to war conflict will directly or indirectly experience a variety of stressors, and many of them may develop common symptoms and reactions such as sadness, anger, fears, numbness, moodiness or irritability, nightmares, avoidance of situations (Amiri, A., \& Zafarzai, I 2020; Hammad, J., and Tribe, R., 2020; Shehadeh, et al, 2016; Barenbaum , Ruchin , SchwabStone, 2004).

Researchers suggested that experiences related to conflict, occupation, political violence and war had a serious risk on the well-functioning of all family members, and many psychological, emotional, physical, and social problems raise (Amiri, A., \& Zafarzai, I 2020; Fawzyiah Hadi, Llabre, \& Spitzer, 2006; Qouta, S, Punamaki, \& El Sarraj, 2003; Dyregrov, Gjestad, \& Raundalen, 2002). Palestinian families living within the occupied territories have been shown to have high rates of psychological and social problems and one to two thirds of the population presenting with trauma-related psychopathologies (Thabet, A., 2019; Thabet et al., 2008; Khamis, 2005; Baker, A.M,. \& Kanan, H.M, 2003).

In Palestine, Conflict started more than 100 years ago. Several generations experienced this kind of conflict since Ottoman rule to British mandate, and later on throughout the Israeli occupation period, it can be considered as the longest conflict in the modern era (Shehadeh ea al, 2016; Bornstein, 2010; Nashif, 2008; Peteet, 1994; Bar-Tal, 1990).

The most resulting action from this situation, that, more than 200 Israeli settlements were established in the West Bank, several settlements of them enclaves inside the city of Hebron especially the old city (Betselem, 2018). Israel governorate has been forcing thousands of Palestinians of their privet lands and homes, taking by military force and illegally settle and create settlements exclusively for Jewish Israeli settlers (Amnesty,2018; Elliott, 2013). Israeli military has established 20 lasting staffed checkpoints in Old Hebron city. Palestinians who need to go through any of these checkpoints must endure lengthy, humiliating inspections (Betselem, 2018). Palestinians living in this area are subjected to extreme restrictions on their movement by car or on foot - including the closure of main streets - while settlers are free to go where they wish. In addition, the military has issued shutdown orders to hundreds of stores and commercial establishments in this area. Families and children who have been subjected to violent experiences may exhibit a variety of responses and symptoms ranging from mild stress to sever trauma (Roney; Srour, 2005; Qouta, Punamäki, El Sarraj, 2008; Garbarino, Kostelny, 2018). 
In contrast to war and political situation and more life stress, the studies show that girls and boys react differently to war related stress (Thabet, A., 2019; Abdeen et al., 2008; Al-Krenawi, LevWiesel \& Sehwail ,2007; Thabet, Abdulah, Elhelou, \& Vostanis, 2006 ; Chimienti \& Abu Nasr, 1992; Hadi \& Llabre, 1998; Llabre \& Hadi, 1997).

Girls tended to experience more related anxieties and emotional problems and to express more separation anxiety than do boys under these specific circumstances, and higher levels of distress (Klingman, Sagi, \& Raviv, 1993; Swenson \& Klingman, 1993), while boys, show more nervous, aggressive, conduct broplems and social misbehavior, or and a collection of all symptoms (Shehadeh et al, 2016; Al-Krenawi, Lev-Wiesel \& Sehwail ,2007; Baker, \& Kanan, 2003; Engel, 1984; Hesse, 1986; Moracco \& Camilleri, 1983), boys reported higher posttraumatic stress symptoms than girls (Llabre \& Hadi, 1997). While no specific differences were found between boys and girls according to other studies (Laor, Wolmer, \& Cohen, 2001). Therefore, we examined gender as a potential moderator.

According to the effects of age, a preponderance of evidence propose that the younger children are the more vulnerable to have psychological problems during stressful and war situations and political (Shehadeh et al, 2016,2016 ;Laor, Wolmer, \& Cohen 2001; Udwin, Boyle, Yule, Bolton, \& O'Ryan, 2000; Rutter, 1993) they are more distressed and more likely to experience fears, emotional and psychological problems, anxiety and depression (Shehadeh, 2015; Vormbrock, 1993; Costello et al., 1994). However, other studies suggest that the older the child is the more symptoms of depression, anxiety and PTSD symptoms he has (Gleser, Green, and Winget;1981\& Green et al., 1991), they were more exposed to a greater number of traumatic events and more likely to witness or be a victim of violence and war (Macksoud \& Nazar ,1993). From the other hand, studies hypothesized that parent's reaction to traumatic experience and violence may impacted with age to influence the children's responses (Yule \& Udwin, 1991, shehadeh et al, 2016), such that parents' reactions influence younger children greater than they do with older children. therefore, it seems that age is a factor that warrants further investigation.

This study thus aims to examining the psychological wellbeing of schoolchildren living among Israeli settlements in the old city of Hebron and test the differences in that impact according to gender and age. 


\section{Methods:}

\section{Study sample}

(POT) is divided into three parts, West Bank east Jerusalem and Gaza, two parts can be considered for this kind of research as Israeli setlemints and Palestinians are living in the same area.

From the Director of Education and High Education in Hebron Governorate, we received a list of all Palestinian schools that are located inside the old city and students have to cross Israeli checkpoints dally. From the director of education and high education in Hebron, we received a list of schools from the selected place, that contain (30) schools out of (152) in all the governorate, number of students in this sight are (8000) student and number of female teachers are (300) teacher and (22) of educational councilors. We asked the director of education and high education in Hebron to randomly select 6 of schools out of 30 . From the chosen schools we asked the councilors to randomly select every fifth name in the students list to reach a sample represented $20 \%$ of all the society study, then asked the students to fill and complete the Strength and Difficulties Questionnaire. Five hundred questionnaires sent to schools to be filed, we received 357 filed ones. See table N: 1.

Table 1. Socio-demographic characteristics of children 2019-2020: Director of Education and High Education in Hebron, 2019.

\begin{tabular}{|l|l|l|l|}
\hline \multicolumn{3}{|l|}{ Total group $(\mathrm{n}=357)$} \\
\hline Gender & Age \\
\hline Mail & $160(44.8 \%)$ & $<12$ & $175(49 \%)$ \\
Female & $197(55.2 \%)$ & $12-18$ & $182(51)$ \\
\hline
\end{tabular}

\section{Procedure}

Data regarding the psychological well being of school aged children were collected in 2019-2020 by the use of the Strength and Difficulties Questionnaire, which was filed in anonymously by 357 children themselves or by parents for the age less than 12 years old. Other copies of the questionnaires which were filed by known children, were also filed by parents and other copies by teachers. Those participants were visited at their schools by the author and one of the councilors who have been trained in research methodology. Children, mothers and teachers were informed about the research and its aims, asked the children and their mothers' consent to participate, and identified students were invited to complete the questioner. The researcher remained to give 
support to respondents if it needed. The questionnaire was accompanied by written information about the study aims, anonymity and confidentiality, researcher's contact information, information about possible referral for mental health support, and completion instructions. The researcher returned the next week to receive the completed questionnaires. Referral for mental health support was available to all participants, upon request.

\section{Measures}

After a sociodemographic questionnaire, investigating age and gender children, parents and teachers were asked to complete self report questionnaire about children psychological well being, strength and difficulties questionnaire (SDQ) already used in Palestinian context and before using the SDQ, it was discussed in a group of five experts from Palestinian universities to verify its stability for research aims and participates.

The (SDQ) (Goodman \& Scott, 1999): This self-questionnaire is widely used to assess the psychological well-being of young people (Goodman \& Scott, 1999; Goodman, 1997). The (SDQ) contains 25 items to be scored on a Likert-scale from (0 to 2) respectively (not true, somewhat true, and certainly true); five subscales are distinguished (pro-social behavior, hyperactivity, emotional symptoms, conduct problems, and peer problems), as also a total difficulties score (sum of the 20 items from the four problems scales). In this study, we used the Arabic translation of the SDQ adolescent version, which has already been used in Palestine (Thabit, Tmtida, \& Fostanis, 2000; Thabet et al. 2010; Shehadeh et al. 2015, 2016). The questionnaire contains 25 items that are scored on a Likert scale from 0 (incorrect) to 2 (definitely true), plus the sum of the difficulty scores. Reliability analyzes showed a (Cronbach's alpha $=.73)$. A total problem scores higher than 20 (pc 85 in our sample) was considered a high score (cut-off score). For the subscales, scores higher than 7 (percentile 85) were considered high scores.

UCLA-PTSD-Reaction Index (UCLA-PTSD-RI) (Rodriguez, Steinberg, \& Pynoos, 1999): the self-report questionnaire is based on the DSM-IV criteria for PTSD, and has been widely used in research on PTSD in children and adolescents (Steinberg et al., 2004), also in Palestine (Shehadeh et al., 2015, 2016; Abdeen et al., 2008). 22 items are scored on a Likert-scale from 0 (never) to 4 (always). For this study, we used the Arabic version, which is adapted to the Palestinian context. The total score is the sum of the 22 items (Cronbach's alpha =.81). Rodriguez et al. (1999) proposed a score of 38 and higher as a clinical. 


\section{Statistical analysis}

Descriptive statistics, t-test, and SD analyzes were used to present sample demographic characteristics and prevalence of psychological problems and to determine the variables impacting the psychological wellbeing of children living among Israeli settlements in Hebron old city (age \& gender), (total PTSD score on UCLA-PTSD-RI,

Total difficulty score on SDQ and subscales of the SDQ, emotional, conduct, hyperactivity and peer relationship problems), analyzes were performed using SSPS (version 22).

\section{Results}

\section{Psychological wellbeing}

Table- 2- Filling by mothers

\begin{tabular}{|c|c|c|c|c|c|c|c|c|c|c|c|c|c|}
\hline 号 & & & $\begin{array}{l}\frac{\tilde{g}}{0} \\
\frac{0}{0}\end{array}$ & $\mathrm{z}$ & $\Sigma$ & $\hat{\Omega}$ & - & 2 & $\underset{<}{80}$ & $\Sigma$ & $\hat{s}$ & - & 2 \\
\hline \multirow{2}{*}{ 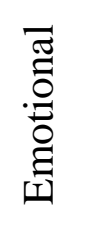 } & \multirow{2}{*}{$\begin{array}{l}\text { है } \\
\text { है: } \\
\text { है: }\end{array}$} & & $\Sigma$ & 8 & $\begin{array}{l}\infty \\
\underset{\sim}{\sim}\end{array}$ & $\stackrel{\circ}{i}$ & ' & \multirow{2}{*}{8} & $v$ & $\stackrel{m}{m}$ & $\stackrel{n}{\sim}$ & \multirow{2}{*}{, $\quad \stackrel{5}{+}$} & \multirow{2}{*}{$\stackrel{\vartheta}{ \pm}$} \\
\hline & & & $\omega_{1}$ & $\hat{a}$ & बे & ָָ & $\stackrel{\infty}{+} m$ & & $\stackrel{\dot{I}}{\simeq}$ & $\underset{\dot{\infty}}{\stackrel{\infty}{\infty}}$ & $\vec{n}$ & & \\
\hline \multirow{2}{*}{$\begin{array}{l}\bar{\Xi} \\
\bar{\Xi} \\
0\end{array}$} & \multirow{2}{*}{$\begin{array}{l}\tilde{E} \\
\frac{0}{0} \\
0 \\
0 \\
0\end{array}$} & & $\Sigma$ & $\stackrel{8}{0}$ & $\ddot{n}$ & $\stackrel{0}{-}$ & \multirow{2}{*}{ 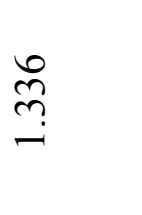 } & \multirow{2}{*}{$\stackrel{\infty}{-}$} & $v$ & $\ddot{n}$ & $\stackrel{+}{-}$ & \multirow{2}{*}{$\stackrel{g}{ \pm}$} & \multirow{2}{*}{$\stackrel{n}{\infty}$} \\
\hline & & & L & $\hat{a}$ & $\stackrel{r}{n}$ & $\stackrel{+}{-}$ & & & $\stackrel{\dot{C}}{=}$ & $\stackrel{\sim}{m}$ & $\stackrel{0}{-}$ & & \\
\hline \multirow{2}{*}{ 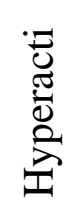 } & \multirow{2}{*}{ 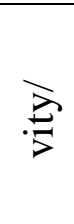 } & : & $\Sigma$ & $\stackrel{8}{8}$ & $\stackrel{\infty}{+}$ & $\stackrel{\infty}{-}$ & \multirow{2}{*}{ กे } & \multirow{2}{*}{$\stackrel{?}{?}$} & $v$ & $\stackrel{0}{i}$ & $\stackrel{\infty}{-}$ & \multirow{2}{*}{$\begin{array}{l}\bar{\infty} \\
\stackrel{\circ}{a}\end{array}$} & \multirow{2}{*}{$\delta$} \\
\hline & & & L & $\hat{a}$ & $\stackrel{r}{\dot{r}}$ & $\stackrel{\infty}{-}$ & & & $\stackrel{\check{I}}{\simeq}$ & $\stackrel{\nabla}{\forall}$ & I & & \\
\hline \multirow{2}{*}{$\ddot{\bar{d}}$} & \multirow{2}{*}{ 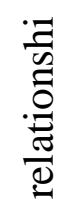 } & & $\Sigma$ & $\stackrel{8}{0}$ & $\stackrel{n}{+}$ & $\stackrel{\ominus}{\oplus}$ & \multirow{2}{*}{, 宂 } & \pm & $v$ & $\stackrel{\circ}{+}$ & $\because$ & \multirow{2}{*}{$\underset{\infty}{ \pm}$} & \multirow{2}{*}{$\stackrel{\ominus}{\stackrel{\gamma}{\gamma}}$} \\
\hline & & & $\omega_{1}$ & $\hat{a}$ & $\stackrel{r}{\dot{*}}$ & $\because$ & & & $\stackrel{1}{\beth}$ & $\stackrel{n}{+}$ & $\dddot{n}$ & & \\
\hline \multirow{2}{*}{\multicolumn{2}{|c|}{ 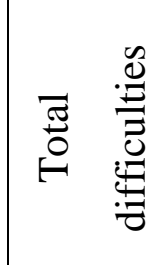 }} & \multirow{2}{*}{ 异 } & $\Sigma$ & $\underset{8}{8}$ & $\hat{\sigma}$ & $\infty$ & \multirow{2}{*}{ 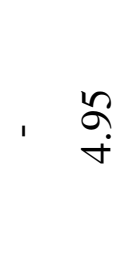 } & \multirow{2}{*}{8} & $\frac{\mathrm{I}}{\mathrm{V}}$ & $\begin{array}{l}\stackrel{\circ}{\circ} \\
\text { ळे }\end{array}$ & ठิ & \multirow{2}{*}{ g } & \multirow{2}{*}{$\begin{array}{l}\infty \\
\infty \\
\infty\end{array}$} \\
\hline & & & I & $\hat{a}$ & $\stackrel{\circ}{\swarrow}$ & సે & & & $\frac{\infty}{\stackrel{1}{c}}$ & $\begin{array}{l}\vec{\circ} \\
\text { бे }\end{array}$ & $\stackrel{\emptyset}{=}$ & & \\
\hline
\end{tabular}

${ }^{*} \mathrm{p}<.05,{ }^{* *} \mathrm{p}<.01,{ }^{* * *} \mathrm{p}<.001$, Strength and difficulties as measured by SDQ Total difficulties : $>$ $20 \&$ Every subscale $>7$ 
For children who were living among Israeli settlements in Hebron old city, mothers reported scores above the threshold, showing they had severe psychological problems (SDQ) in total difficulties and emotional problems in favor of females, whereas hyperactivity problems have been recorded in favor of children aged less than 12 .

Table-3- Filling by teachers:

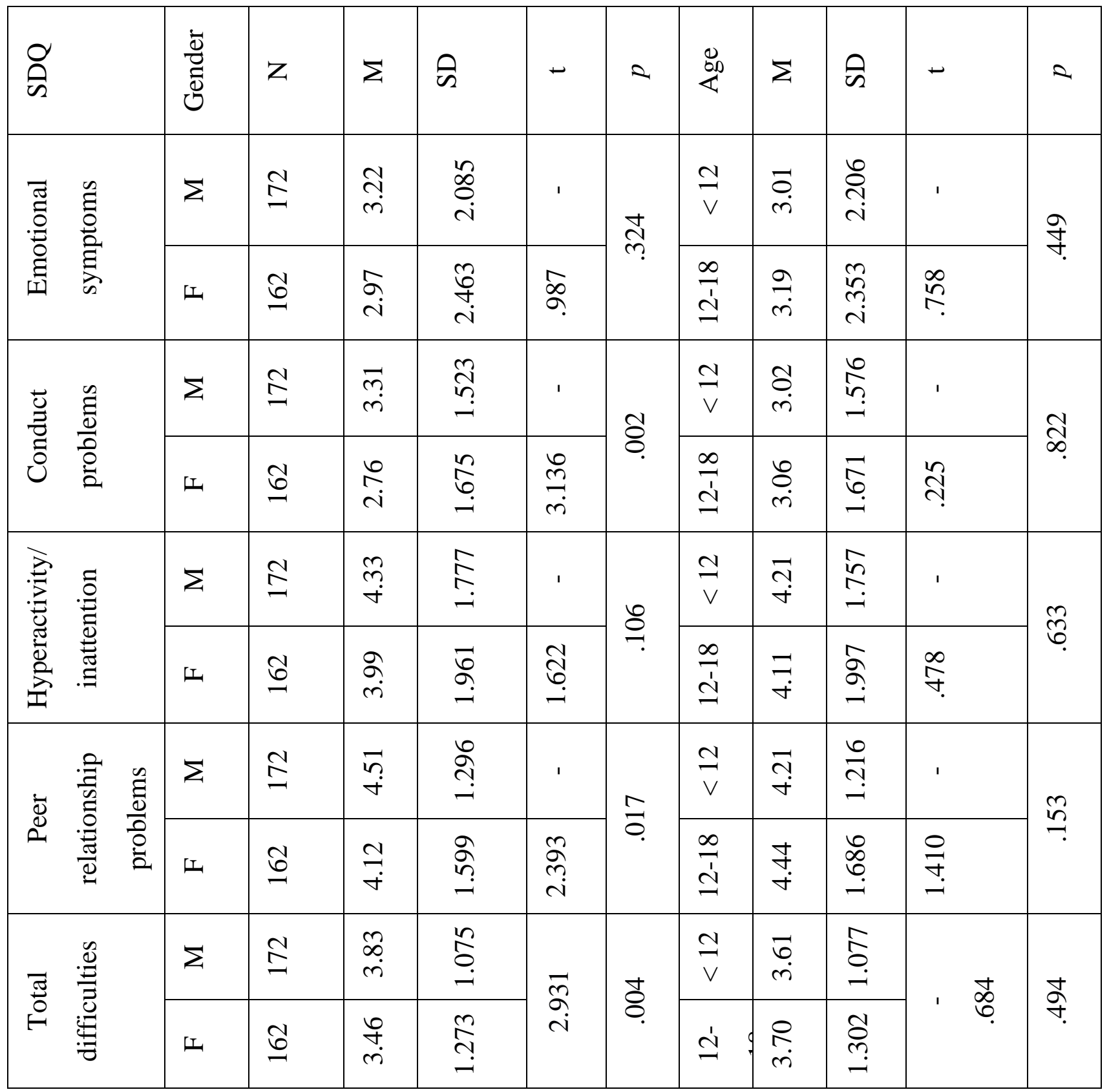

$* \mathrm{p}<.05, * * \mathrm{p}<.01, * * * \mathrm{p}<.001$, Strength and difficulties as measured by SDQ Total difficulties : $>$ $20 \&$ Every subscale $>7$

Teachers reported for Palestinian children who were living among Israeli settlements in Hebron old city, that they score above the threshold in (SDQ), total difficulties, conduct 
Academic Journal of Research and Scientific Publishing | Vol 3 | Issue 28

Publication Date: 5-8-2021 ISSN: 2706-6495

problems and peer relationship problems in favor of mails, this showed that they had severe psychological problems.

Table-4- Filling by Children themselves

\begin{tabular}{|c|c|c|c|c|c|c|c|c|c|c|c|c|c|}
\hline$\stackrel{\circ}{\circ}$ & & & $\begin{array}{l}\dot{\bar{\theta}} \\
\overline{0} \\
\stackrel{0}{0}\end{array}$ & Z & $\Sigma$ & $\hat{\Omega}$ & - & 2 & $\underset{\&}{\infty}$ & $\Sigma$ & $\hat{\Omega}$ & - & 2 \\
\hline \multirow{2}{*}{. } & \multirow{2}{*}{\multicolumn{2}{|c|}{ 華 }} & $\Sigma$ & 导 & $\begin{array}{l}\bar{\infty} \\
i\end{array}$ & ‡ั & 1 & \multirow{2}{*}{8} & $\frac{\mathrm{J}}{\mathrm{V}}$ & $\underset{\infty}{\infty}$ & $\begin{array}{l}\hat{b} \\
\text { ì }\end{array}$ & 1 & \multirow{2}{*}{$\stackrel{\infty}{8}$} \\
\hline & & & IL & $\underset{\Xi}{ \pm}$ & $\stackrel{\text { }}{\underset{+}{+}}$ & 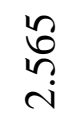 & 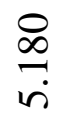 & & $\stackrel{\sim}{\sim}$ & $\begin{array}{l}\infty \\
\dot{m} \\
\dot{m}\end{array}$ & $\hat{n}$ & $\begin{array}{l}\stackrel{\rho}{\infty} \\
\infty \\
\infty\end{array}$ & \\
\hline \multirow{2}{*}{\multicolumn{2}{|c|}{$\begin{array}{l}\overline{0} \\
\frac{0}{0} \\
\tilde{0}\end{array}$}} & \multirow{2}{*}{$\begin{array}{l}\frac{n}{E} \\
\frac{0}{0} \\
0 \\
\frac{0}{2}\end{array}$} & $\sum$ & 寺 & $\stackrel{\grave{n}}{m}$ & 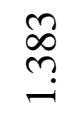 & 1 & \multirow{2}{*}{$\frac{t}{a}$} & $\frac{v}{v}$ & $\stackrel{\infty}{m}$ & 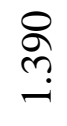 & 1 & \multirow{2}{*}{$\stackrel{N}{n}$} \\
\hline & & & IL & $\underset{ \pm}{ \pm}$ & $\stackrel{\infty}{\stackrel{\infty}{n}}$ & ñ & $\stackrel{m}{\tilde{c}}$ & & $\frac{\infty}{\stackrel{1}{c}}$ & $\stackrel{\widetilde{N}}{\ddot{n}}$ & 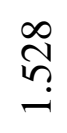 & \& & \\
\hline \multirow{2}{*}{ 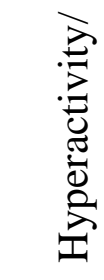 } & \multirow{2}{*}{\multicolumn{2}{|c|}{ 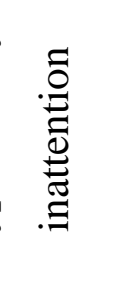 }} & $\Sigma$ & 寸 & $\stackrel{m}{\vartheta}$ & $\underset{\overbrace{}}{\widetilde{\sigma}}$ & 1 & \multirow{2}{*}{ \& } & $\frac{v}{v}$ & $\stackrel{n}{r}$ & 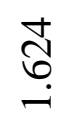 & 1 & \multirow{2}{*}{$\underset{\infty}{\infty}$} \\
\hline & & & IL & $\underset{J}{ \pm}$ & $\underset{\forall}{\stackrel{f}{+}}$ & $\underset{\sim}{\stackrel{\sim}{\sim}}$ & $\overline{5}$ & & $\frac{\infty}{\stackrel{\prime}{c}}$ & 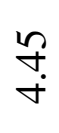 & $\stackrel{\sim}{\stackrel{N}{r}}$ & \&े & \\
\hline \multirow{2}{*}{\multicolumn{3}{|c|}{ 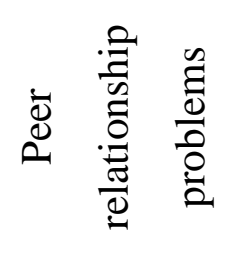 }} & $\Sigma$ & Ð & $\frac{ \pm}{\dot{n}}$ & 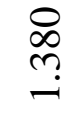 & ' & \multirow{2}{*}{$\stackrel{m}{r}$} & $\frac{\mathrm{V}}{\mathrm{V}}$ & 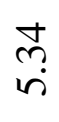 & $\stackrel{+}{\stackrel{+}{~}}$ & ' & \multirow{2}{*}{$\overline{\mathrm{O}}$} \\
\hline & & & IL & $\underset{J}{ \pm}$ & $\begin{array}{l}\overrightarrow{0} \\
\dot{n}\end{array}$ & $\stackrel{\sim}{\sim}$ & $\stackrel{N}{n}$ & & $\stackrel{\text { ㄱ }}{\simeq}$ & $\hat{\gamma}$ & 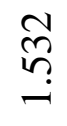 & $\begin{array}{l}\text { ָे } \\
\text { ָे }\end{array}$ & \\
\hline \multirow{2}{*}{\multicolumn{3}{|c|}{ 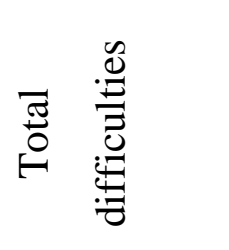 }} & $\Sigma$ & 导 & $\stackrel{a}{\hat{m}}$ & હે & ' & \multirow{2}{*}{ ڤె. } & $\frac{v}{v}$ & $\underset{\forall}{\exists}$ & $\begin{array}{l}+ \\
\stackrel{\infty}{9}\end{array}$ & 1 & \multirow{2}{*}{$\stackrel{\stackrel{ }{\tau}}{\sim}$} \\
\hline & & & IL & $\underset{ \pm}{ \pm}$ & $\stackrel{\underset{\forall}{\sim}}{\underset{\forall}{*}}$ & $\stackrel{\substack{n \\
n}}{n}$ & $\frac{9}{2}$ & & $\frac{\infty}{\stackrel{\prime}{c}}$ & $\underset{+}{\stackrel{\circ}{+}}$ & $\stackrel{+}{m}$ & ते & \\
\hline
\end{tabular}

$* \mathrm{p}<.05, * * \mathrm{p}<.01, * * * \mathrm{p}<.001$, Strength and difficulties as measured by SDQ Total difficulties :> $20 \&$ Every subscale $>7$

Children who were living among Israeli settlements in Hebron old city, reported scores above the threshold, showing they had severe psychological problems (SDQ) in total difficulties and emotional problems in favor of females, whereas peer relation problems have been recorded in favor of children aged less than 12 . 
Table-5- PTSD Filling by children

\begin{tabular}{|l|l|c|c|c|c|c|c|c|c|c|c|c|}
\hline & Gender & & $\mathrm{N}$ & $\mathrm{M}$ & $\mathrm{SD}$ & $\mathrm{t}$ & $p$ & Age & $\mathrm{M}$ & $\mathrm{SD}$ & $\mathrm{t}$ & $p$ \\
\hline Total & $\mathrm{M}$ & & 194 & 2.79 & .701 & - & .032 & $<12$ & 2.97 & .646 & - & .003 \\
\cline { 2 - 9 } PTSD & $\mathrm{F}$ & & 167 & 2.94 & .582 & 2.130 & & $\begin{array}{l}12- \\
18\end{array}$ & 2.77 & .644 & 2.973 & \\
& & & & & & & & & & \\
\hline
\end{tabular}

${ }^{*} \mathrm{p}<.05,{ }^{* *} \mathrm{p}<.01,{ }^{* * *} \mathrm{p}<.001$, PTSD: posttraumatic stress disorder as measured by the USCL-

PTSD Reaction Index Questionnaire

Mothers reported scores above the threshold who are aged less than 12 , showing that children had severe symptoms of posttraumatic stress (UCLA-PTSD-RI). According to gender, children reported scores above the threshold in favor of females.

\section{Discussion}

The aim of the study was, to investigate the impact of living among Israeli settlements in old city of Hebron, which happening in contexts of protracted armed conflicts in (POT)' and its effect on the psychological wellbeing of young Palestinian children. These children are more likely to develop psychological difficulties, and even more likely to develop symptoms of posttraumatic stress.

Although these findings are in line with earlier findings suggesting that living within the contest of war or political conflict associated with higher mental health and psychological problems (Hammad ,J and Tribe, R, 2020; Thabet, et al, 2008; Hasanovic, et al; 2006).

Our sample showed very high levels of clinical scores (Amiri, A., \& Zafarzai, I, 2020; Shehadeh et al, 2015,2016 Fawzyiah Hadi, Llabre, \& Spitzer, 2006).

Besides the overall risk to developing mental health problems in these children, we found that females even show a higher risk, in particular to develop PTSD symptoms. And in the reports filed by children themselves and others which filed by their mothers (Reports belong to total SDQ and emotional problems subscale. One hypothesis here could be that female children are more likely to being influenced by their parents' response to traumatic events, such as living within daily political conflict and daily crossing Israeli soldiers' checkpoints (Shehadeh et al , 2015, 2016; Thabet et al, 2010; Thabet et al, 2006; Al-Krenawi, Lev-Wiesel \& Sehwail ,2007; Baker, \& Kanan, 2003; Laor et al., 2001; Udwin et al., 2000).

Considering age, the study findings indicate that the younger the child is, the more a higher risk, in particular to develop PTSD symptoms and more psychological and behavioral problems(SDQ); 
hyperactivity and peer relationship problems, (s)he might have as a consequence of being lived within Israeli settlement and ongoing conflect. This finding might be consistent with previous studies, suggesting that younger children are more likely to being influenced by their families' responses to traumatic or stressful events than older children (Shehadeh et al, 2015, 2016; Baker, A, \& Kanan, H, 2003; Udwin et al, 2000; Miller et al ,1999).

Older children in society of Palestinian are often expected to take over, when needed, the role of the household head. This particular role, possibly associated with a higher sense of responsibility towards their families, and as result, this may have reduced the PTSD levels in these older participants (Jordans, 2010; Thabet et al, 2010, Pierce et al., 1998). Another hypothesis could be that the cultural context impacts a tendency to avoid the expression of feelings, which might have led to an underreport of symptoms (Thabet, 2019; Udwin, et al, 2000; Kelley, 1994). Above, older adolescents might be more able to adjust with these impacting experiences, possibly also because of the higher support they received from a rounding friend.

On the other hand, and considering gender differences as teachers recorded, the study findings indicate that the child male is, the higher risk to develop psychological and behavioral problems(SDQ); total difficulties, conduct and peer relationship problems, these findings are in line with earlier findings suggesting that,

being within context of ongoing war and conflict such as the (POT) "as hot points; old city in Hebron" (Shehadeh et al, 2016; Abdeen et al 2008; Baker, A, \& Kanan, H, 2003; Dyregrov, A, Gjestad, R, \& Raundalen, M, 2002).

Exposed to ongoing conflict and violence have higher effect on the psychological wellbeing on children and adolescence, on the other hand our results were not on line with other studies performed in South Africaas a place that children were being exposed to political violence directly or indirectly, the mostly common symptoms were sleeping problems, avoidance thoughts and activities associated with trauma and hyper vigilance (Seedat, Van Noord, Vythilingum, Stein, 2000; Peltzer, 1999; Dawes, Tredoux, Feinstein, 1989;), other studies that have been done in such situation (Malone et al., 2010; Pat-Horenczyk et al., 2009; Miller et al., 1999), this can be explained according to the effect of living within hot places and continues conflict and its affect upon psychological wellbeing of children. 


\section{Implications:}

Given the large impact of living within war-affected contexts onto families and children, it is clear that the first implication should be that Israeli occupation on (OPT) should be ended and the conflict also should be ended, in order to minimize the impact of war and conflict onto children and adolescents. But as long as conflicts continue our findings indicate that these children and adolescents need support and assistance, in particular psychological and social support. These interventions should be oriented to all family members, especially children. Hereby, counselors, teachers, and therapists must be aware of the particular context, and must be traind in such kinds of systemic intervention.

\section{Limitations:}

First: We collected data in only one part of the (OPT), so the generalizability of our study results may be limited.

Second: We measured only PTSD symptoms and general psychological problems (SDQ), while other mental health problems may be of significant importance in this population. Therefore, future research needs to include a range of other psychological problems.

\section{References:}

\section{References:}

Abdeen, Z., Qasrawi, R., Nabil, S., \& Shaheen, M. (2008). Psychological reaction to Israeli occupation: Findings from national study of school-based screening in Palestine. International Journal of Behavioral Development, 32, 290- 297.

Al-Krenawi, A., Lev-Wiesel,R.,. Sehwail , M .(2007).Psychological Symptomatology among Palestinian Male and Female Adolescents Living under Political Violence 20042005.Community Mental Health Journal, (43), 1, 49-56. DOI: 10.1007/s10597-006-9060-9

Amiri, A., \& Zafarzai, I (2020). Political violence and its effects on physical and mental health. International Journal of Academic Research in Business and Social Sciences, 11(1), 466-474. Amnesty International (2017). Amnesty International Report 2017/2018: The state of the world's human rights. Retrieved from

https://www.amnesty.org/en/latest/campaigns/2017/06/israel-occupation-50-years-ofdispossession

Baker, A.M. \& Kanan, H.M. (2003). Psychological Impact of Military Violence on Children as a Function of Distance from Traumatic Event: The Palestine case. Intervention, 1(3), 13-21. 
Barenbaum J, Ruchin V, Schwab-Stone, M (2004) The psychosocial aspects of children exposed to war: practice and policy initiatives. J Child Psychol Psychiatry 45:41-62.

Bar-Tal, D. (1990). Israeli-Palestinian Conflict: A cognitive Analysis.. International Journal of International Relations, 14, 7-29.doi:10.1016/0147-1767(90)90045-X.

Bornstein, A. (2010). Palestinian prison ontologies. Dialectical Anthropology, 34(4), 459-472. doi:10.1007/s10624-010-9197-3.

Chimienti, G., \& Abu Nasr, J. (1992). Children's reactions to war-related stress. 11: The influence of gender, age, and the mother's reaction. International Journal of Mental Health, 21(4), 72-86.

Dawes,A., Tredoux.,C,. Feinstein, A. (1989). Political violence in South Africa: Some effects on children of the violent destruction of their community. International Journal of Mental Health, 18, (7): 16-43.

Costello, M., Phelps, L., \& Wilczenski, F. (1994). Children and military conflict: Current issues and treatment implications. The School Counselor, 41,220-225.

Dyregrov, A., Gjestad, R., \& Raundalen, M. (2002). Children exposed to warfare: a longitudinal study. Journal of Traumatic Stress, 15(1), 59-68. doi:10.1023/A:1014335312219.

Engel, M. (1984). Children and war. Peabody Journal of Education, 61(3), 71-90.

Garbarino, J., \& Kostelny, K. (1996). The Effects of Political Violence on Palestinian Children's Behavior Problems: A Risk Accumulation Model. Child Development, 67(1), 33. doi: $10.2307 / 1131684$.

Gleser, G., Green, B. L., \& Winget, C. (1981). Prolonged psychosocial effects of disaster: A study of Buffalo Creek. New York: Academic Press.

Macksoud, M. S., \& Nazar, F. A. (1993). The impact of the Iraqi occupation on the psychological development of children in Kuwait. Paper prepared for the Kuwait Society for the Advancement of Arab Children.

Hadi F, Llabre M, Spitzer S (2006) Gulf War-related trauma and psychological distress of Kuwaiti children and their mothers. J Trauma Stress 19: 653-662.

Hadi, F. A., \& Llabre, M. M. (1998). The Gulf Crisis of Kuwaiti children: Psychological and cognitive factors. Journal of Traumatic Stress, 11, 45-56. 
Hammad ,J and Tribe, R.(2020). Social suffering and the psychological impact of structural violence and economic oppression in an ongoing conflict setting: The Gaza Strip. Journal of community psychology, 48; (6): 1791-1810. https://doi.org/10.1002/jcop.22367.

Hammack, P. L. (2006). Identity, Conflict, and Coexistence: Life Stories of Israeli and Palestinian Adolescents. Journal of Adolescent Research, 21(4), 323-369. doi: $10.1177 / 0743558406289745$.

Hasanovic, M; Sinanovic, O; Selimbasic, Z; Pajevic; Avdibegovic, E (2006). Psychological Disturbances of War-traumatized Children from Different Foster and Family Settings in Bosnia and Herzegovina. Clinical Science; 47: 85-94.

Hesse, P. (1986). Children's and adolescents' fears of nuclear war: Is our sense of the future disappearing? International Journal qf Mental Healt,15, 93-1 13.

Elliott, J. (January,31,2013). Students suffer as Israel denies Palestinian freedom of movement and education in the occupied territories. https://mondoweiss.net/2013/01/palestinianeducation-territories

Jordans. (2010). Development of a multi-layered psychosocial care system for children in areas of political violence. International Mental Health System. 16; 4-15.

Khamis,V (2005). Post-traumatic stress disorder among school age Palestinian children. Child Abuse Neglected ;29(1):81-95.

Klingman, A., Sagi, A., \& Raviv, A. (1993). The effect of war on Israeli children. In L. A. Leavitt $\&$ N. A. Fox (Eds.), The psychological effects of war and violence on children (pp. 75-92). Hillsdale, NJ: Erlbaum.

Laor, N., Wolmer, L., \& Cohen, D. (2001). Mothers' functioning and children's symptoms 5 years after a SCUD missile attack. American Journal of Psychiatry, 158, 1020-1026.

Llabre,M.M., \& Hadi, F. A. (1997). Social support and psychological distress in Kuwaiti boys and girls exposed to the Gulf crisis. Journal of Clinical Child Psychology, 26, 247-255.

Lystad, M. (1984). Children's responses to disaster: Family implications. International Journal of Family Psychiatry, 51,4 1-60.

Malone, P.S., Lansford, J.E., Castellino, D.R., Berlin, L.J., Dodge, K.A., \& Pettit, G.S. (2010). Divorce and Child Behavior Problems: Applying Latent Change Score Models to Life Event Data. Structural Equation Modeling, 11(3), 401-423. doi:10.1207/s15328007sem1103 
Moracco, J. C., \& Camilleri, J. (1983). A study of fears in elementary school children. Elementary School Guidance and Counseling, 18(2), 82-87.

Nader, K., Pynoos, R., Fairbanks, L., Frederick, C., Al-Ajeel, M., \& Al-Asfour, A. (1993). A preliminary study of PTSD and grief among the children of Kuwait following the Gulf crisis. British Journal of Clinical Psychology, 32, 407-416.

Nashif, E. (2008). Palestinian political prisoners: Identity and community. New-York: Routledge. Pat-Horenczyk, R., Qasrawi, R., Lesack, R., Haj-Yahia, M., Peled, O., Shaheen, M., Abdeen, Z. (2009). Posttraumatic Symptoms, Functional Impairment, and Coping among Adolescents on Both Sides of the Israeli-Palestinian Conflict: A Cross-Cultural Approach. Applied Psychology, 58(4), 688-708. doi:10.1111/j.1464-0597.2008.00372.x

Peltzer, K (1999). Posttraumatic stress symptoms in a population of rural children in South Africa. Psychological Reports, 85(2):646-650.

Qouta, S., Punamäki, R.-L., \& El Sarraj, E. (2003). Prevalence and determinants of PTSD among Palestinian children exposed to military violence. European Child \& Adolescent Psychiatry, 12(6), 265-72. doi:10.1007/s00787-003-0328 0.

Rosenthal, M. K., \& Levy-Shiff, R. (1 993). Threat of missile attacks in the Gulf War: Mothers' perceptions of young children's reactions. American Journal of Orthopsychiatry, 63, 24 1-254. Rouhana, N., \& Bar-Tal, D. (1998). Psychological Dynamics of Intractable Ethnonational Conflicts The Israeli-Palestinian Case. American Psychological Association, 53(7), 761-770.

Rutter, M. (1993). Resilience: Some conceptual considerations. Journal of Adolescent Health, 14, 626-631.

Seedat, S., Van Noord, E., Vythilingum, B., Stein, D.J., Kaminer, D.( 2000). School survey of exposure to violence and posttraumatic stress symptoms in adolescents. South African Journal of Child and Adolescent Mental Health, 12(1):38- 44.

Shehadeh, A; Loots, G; vanderfaeillie, J; Derluyn, I (2016). The Association Between Parental Imprisonment and the Mental Health of Palestinian Adolescents. Child and Adolescents Mental Health, 21; (3): 154-160.

Shehadeh A, Loots G, Vanderfaeillie J, Derluyn I (2015) The Impact of Parental Detention on the

Psychological Wellbeing of Palestinian Children. PLoS ONE 10(7): e0133347. https://doi.org/10.1371/journal.pone.0133347.

Swedenburg, T. (1995). Memories of revolt. Minneapolis: University of Minnesota Press. 
Swenson, C. C., \& Klingman, A. (1993). Children and war. In C. F. Saylor (Ed.), Children and disasters (pp. 137-163). New York: Plenum Press.

Thabet, A.(2019). Psychological Well-Being of Palestinian Children and Adolescents in Gaza

Strip and West Bank: Review Paper. EC Psychology and Psychiatry 8.3 :197-205.

Thabet AM, AL-Ghamdi H, Abdulla T, Elhelou MW, Vostanis P (2010) Attention deficithyperactivity symptoms among Palestinian children. Eastern Mediterranean Health Journal 16: 505-510.

Thabet, A; Abu Tawahina, A; El Sarraj, E ; Vostanis, P .(2007). Exposure to war trauma and PTSD among parents and children in the Gaza strip, Early Child Adolescent Psychiatry, xx:110 DOI 10.1007/s00787-007-0653-9.

Thabet, A.-A., Abdulah, T., Elhelou, M., \& Vostanis, P. (2006). Effect of trauma on Palestinian children's mental health in the Gaza Strip and West Bank. In C. Greenbaum, P. Veerman \& N. Bacon-Shnor (Eds.), Protection of children during armed political conflict: A multidisciplinary perspective (pp. 123-143). Oxford: Intersentia-Antwerpen.

Udwin, O., Boyle, S., Yule, W., Bolton, D., \& O’Ryan, D. (2000). Risk factors for long-term psychological effects of a disaster experienced in adolescence: Predictors of post traumatic stress disorder. Journal of Child Psychology and Psychiatry and Allied Disciplines, 41, 969979.

Vormbrock, J. K. (1 993). Attachment theory as applied to wartime and job-related marital separation. Psychological Bulletin, 114, 122-144.

WAFA,(2021). The impact of Israeli settlement on water in Palestine. https://info.wafa.ps/ar_page.aspx?id=4077.

Yule, W., \& Udwin, O. (1991). Screening child survivors for posttraumatic stress disorder: Experiences from the 'Jupiter' sinking. British Journal of Clinical Psychology, 30, 139-149.

Copyright (C) 2021 Dr. Amer Shehadeh, AJRSP. This is an open-access article distributed under the terms of the Creative Commons Attribution License (CC BY NC).

Doi: doi.org/10.52132/Ajrsp.e.2021.282 